\title{
SEKOLAH GRATIS, SEKOLAH TAK BERDAYA
}

\author{
B.P. Sitepu
}

\begin{abstract}
In the compulsory basic education program, the Government implements a set of policies, one of which is providing funds directly to schools through Block Grant or Operational Fund Assistance. This policy is expected to strengthen school capability in managing and developing school activities to improve the instructional quality and to give more opportunity for school age children to attend schools. Based on the observation at two government primary schools in Jakarta, it is found out that the policy has weakened the school creativity due to the strict regulations and supervision on the usage of the fund provided by the Government. The educational activities previuosly developed and funded under school initiatives have to be terminated as in the present regulation the schools are not allowed to find financial resources, while the fund provided by the Government is not enough to support the activities. The school master will have serious sanctions if he/she does not follow the regulations properly. This study suggests the existing regulations should be reviewed and improved.
\end{abstract}

Key words: desentralisasi, manajemen berbasis sekolah, kreativitas.

\section{PENDAHULUAN}

Dalam upaya mencerdaskan kehidupan bangsa dengan sumber daya manusia yang berkualitas, Pemerintah dan masyarakat Indonesia melaksanakan program wajib belajar pendidikan dasar. Pada tahun 1984 Pemerintah mencanangkan pelaksanaan program wajib belajar pendidikan dasar (wajar dikdas) enam tahun dan sepuluh tahun kemudian, tahun 1994, program wajar dikdas ditingkatkan dari enam menjadi sembilan tahun. Pada waktunya nanti program wajar dikdas diharapkan dapat dilanjutkan menjadi duabelas tahun atau setingkat sekolah lanjutan atas. Dengan demikian, kualitas sumber daya manusia Indonesia dapat ditingkatkan secara bertahap sehingga menjadi bangsa yang cerdas dan mampu berkolaborasi serta bersaing dengan bangsa lain. Penyelenggaraan pendidikan secara massal dengan jumlah besar memerlukan dana yang besar pula untuk membiayai sarana dan prasarana pendidikan serta untuk membayar pendidik dan tenaga kependidikan. Walaupun telah menerapkan program wajar dikdas enam tahun sejak tahun 1984 dan wajar dikdas sembilan tahun mulai tahun 1994, Pemerintah belum dapat memberikan sanksi hukum kepada anak usia sekolah yang tidak mengikuti program wajar tersebut. Keterbatasan kemampuan Pemerintah menyediakan gedung, peralatan pendidikan, dana, serta tenaga kependidikan dalam jumlah yang cukup, mengakibatkan kewajiban mengikuti Program Wajar Dikdas masih terbatas pada himbauan.

Setelah Indonesia merdeka dan melakukan pembangunan di berbagai sektor kehidupan lebih dari setengah abad, ternyata sistem pendidikan nasional masih belum dapat menghasilkan sumber daya manusia yang mampu meningkatkan kecerdasan kehidupan bangsa secara menyeluruh. Memprihatinkannya mutu hasil pendidikan disebabkan oleh berbagai faktor yang antara lain ialah jumlah dana untuk pendidikan kurang memadai. Sampai dengan tahun 2004, dana untuk penyelenggaraan pendidikan tidak sampai mencapai enam persen dari anggaran pendapatan dan belanja negara. Kekurangan dana dari Pemerintah di satu pihak dan tuntutan peningkatan mutu pendidikan di pihak lain, mendorong sekolah melalui mekanisme tertentu membebani orangtua menutupi kekurangan dana untuk penyelenggaraan pendidikan dalam berbagai bentuk sumbangan seperti sumbangan untuk kegiatan ekstrakurikuler, pengadaan peralatan pendidikan, untuk rehabilitasi dan pembangunan gedung, serta kesejahteraan pendidik dan tenaga kependidikan. Walaupun namanya sumbangan tetapi kenyataannya merupakan beban wajib bagi orang tua siswa.

Dalam keadaan ekonomi yang semakin sulit, banyak masyarakat merasa biaya pendidikan anak semakin berat dan menjadi alasan untuk tidak menyekolahkan anaknya. Berbagai kasus lain yang memprihatinkan bermunculan. Ada siswa yang mencoba bunuh diri karena malu dan stress tidak mampu melunasi uang sekolahnya selama beberapa bulan. Kenyataan ini tentu tidak sesuai dengan keinginan dalam UUD 1945 bahwa setiap warga negara Indonesia berhak untuk memperoleh pendidikan.

Oleh karena itu, dalam Amandemen UndangUndang Dasar 1945 tahun 2002 disebutkan, Negara memperioritaskan anggaran pendidikan sekurangkurangnya $20 \%$ dari anggaran pendapatan dan 
belanja negara serta dari anggaran pendapatan dan belanja daerah untuk memenuhi kebutuhan pendidikan nasional. Ketentuan itu menuntut Pemerintah untuk meningkatkan dana penyelenggaraan pendidikan sampai $20 \%$ yang bersumber dari APBN dan APBD. Kalau tidak, Pemerintah dianggap melanggar konstitusi.

Pemerintah telah berupaya meningkatkan dana penyelenggaraan pendidikan melalui APBN dan APBD mulai tahun 2004, misalnya melalui program Block Grant dan Bantuan Operasional Sekolah (BOS) yang dialokasikan langsung ke sekolah. Dengan demikian sekolah diharapkan tidak lagi membebani orangtua dan masyarakat dengan berbagai pungutan dan siswa benar-benar dapat menikmati pendidikan gratis dengan tentram .

\section{Masalah}

Bagaimana kenyataannya sesudah Pemerintah melakukan desentralisasi dana penyelenggaran pendidikan ke sekolah? Apakah pelaksanaan Manajemen Berbasis Sekolah (MBS) semakin nyata dan berhasil meningkatkan efisiensi dan efektifitas penyelenggaraan pendidikan di sekolah? Benarkah pendidikan itu menjadi gratis? Bagaimana perkembangan prakarsa sekolah dalam memajukan pendidikan di sekolah? Apakah mutu penyelenggaraan dan hasil pendidikan di sekolah semakin bertambah baik? Pertanyaan-pertanyaan itu cukup mengusik dan menarik untuk dicermati dan dicarikan jawabannya.

\section{Pengamatan ke Sekolah}

Tulisan ini mencoba memberikan jawaban sementara dengan mengamati kenyataan di Sekolah Dasar yang cukup unik di Jakarta Pusat. Disebut jawaban sementara karena hasil pengamatan itu terbatas pada sekolah tertentu yang tidak mewakili semua SD, akan tetapi diharapkan dapat memberikan indikasi perlunya penelitian yang lebih mendalam dan menyeluruh. SD yang diamati dianggap unik karena berada dalam komplek yang menyatu dengan SMP dan SMA dan dulunya (tahun 1981) direncanakan merupakan pendidikan terpadu mulai dari SD, SMP, dan SMA. Akan tetapi dalam perjalanannya keterpaduan itu semakin pudar dan tidak nyata dilihat dari proses pembelajaran maupun dari pengelolaannya. Ketiga unit sekolah yang berstatus Negeri itu dipisahkan dengan pagar dan jalan lingkungan. Enam unit SD (SD Negeri Kenari No. 7 s.d. No. 12) berada dalam satu komplek menempati gedung berlantai tiga. SMP Negeri No. 216 menempati gedung yang terpisah pula dengan gedung SMA
Negeri No. 68. Masing-masing sekolah berjalan sendiri-sendiri. Akan tetapi dengan diberlakukannya program wajar dikdas sembilan tahun, rapat koordinasi Kepala SD dan SMP mulai dilakukan lagi.

Gedung SD yang berlokasi pada bagian belakang komplek sekolah terpadu itu terdiri atas tiga lantai dan dipakai oleh enam SD dengan jumlah tidak kurang dari 1.200 siswa secara keseluruhan atau setiap SD memiliki rata-rata 200 siswa. Masingmasing SD dipimpin oleh seorang kepala sekolah tanpa wakil. Keenam SD itu menyelanggarakan pembelajaran pagi hari dan menggunakan petang dan sore hari untuk kegiatan ekstrakurikuler. Dengan demikian lingkungan sekolah itu selalu ramai dengan berbagai kegiatan belajar dan membelajarkan.

Data dan informasi dikumpulkan dengan cara melakukan pengamatan dan wawancara di dua dari enam SD tersebut, yaitu SD Negeri Kenari No. 7 dan No. 8. yang kedua-duanya menempati ruang kelas di lantai dasar. Kedua SD itu dipilih atas dasar pertimbangan masing-masing kepala sekolahnya memiliki banyak pengalaman mengelola SD dan juga sebagai guru kelas. Kedua SD ini dipimpin oleh kepala sekolah yang telah memperoleh cukup banyak pengalaman sebagai kepala sekolah. Kepala SD Negeri Kenari No. 08 misalnya, setelah mengajar sebagai guru kelas sembilan tahun, diangkat menjadi Kepala SD pada tahun 1993 dan telah mengalami perpindahan atau rolling sebanyak tiga kali.

Pengamatan dilakukan pada proses belajarmembelajarkan di kelas, sarana dan prasarana di sekolah. Sementara itu Kepala Sekolah dan guru diwawancarai untuk memperoleh data dan informasi lebih lanjut yang kemudian diolah, dianalisis, serta didiskusikan untuk menarik kesimpulan. Pengamatan ke sekolah ini dimaksudkan sebagai kajian awal untuk kajian yang lebih lanjut dan lebih luas sehinga hasilnya dapat lebih meyakinkan serta dapat dijadikan generalisasi.

\section{Hasil Pengamatan}

Secara garis besar data dan informasi yang diperoleh dari hasil pengamatan dan wawancara dikelompokkan pada keadaan sekolah sebelum dan sesudah desentralisasi dana penyelenggaraan pendidikan ke sekolah. Penyajian data dan informasi berikut ini difokuskan pada kegiataan belajarmembelajarkan, pembiayaan, dan mutu proses dan hasil belajar-membelajarkan. 


\section{Keadaan Sekolah Sebelum Desentralisasi Dana Penyelenggaraan Pendidikan}

Ketika dana BOS belum ada, kedua sekolah ini berupaya mendorong partisipasi orang tua dan masyarakat dalam berbagai bentuk untuk meningkatkan mutu pendidikan. Dengan bermusyawarah dan bekerja sama dengan Persatuan Orangtua Murid dan Guru yang kemudian berubah menjadi Komite Sekolah, kedua sekolah ini meningkatkan pelayanan pendidikan sehingga mampu bersaing dengan sekolah lain. Keterbatasan dana Biaya Operasional Pendidikan (BOP) diatasi dengan memberdayakan kemampuan orangtua dan masyarakat.

Kreativitas guru dan Kepala Sekolah dalam memberikan pelayanan pendidikan mengakibatkan sekolah ini sering unggul dalam berbagai perlombaan di tingkat kecamatan, kotamadya dan se-DKI Jakarta. Oleh karena itu, tidak mengherankan kalau sekolah ini sering mendapat kunjungan dan dijadikan penelitian dari berbagai pihak termasuk dari luar negeri, walaupun sekolah ini tidak termasuk sekolah percontohan. Diakui oleh kedua Kepala SD ini bahwa prestasi yang dicapai tidak dapat dipisahkan dari peranserta dan tanggung jawab orang tua dan masyarakat. Latar belakang sosial dan ekonomi orangtua siswa sangat bervariasi, mulai dari pedagang sayur sampai angota DPRD dan pejabat tinggi Pemerintah Daerah. Tetap pada umumnya mereka sangat peduli terhadap pendidikan anak-anaknya.

Oleh karena keadaan ekonomi orang tua bervariasi dan ada juga yang tergolong tidak mampu, maka penggalangan dana partisipasi orangtua disesuaikan dengan kemampuannya, tanpa ada unsur paksaan. Semua program yang diajukan sekolah melalui musyawarah dan persetujuan guru dan komite sekolah. Sambutan positif dari orangtua, guru, dan siswa memotivasi kepala sekolah terus menerus melakukan prakarsa meningkatkan pelayanan pendidikan sehingga proses pembelajaran lebih kreatif, efektif, efisien dan menyenangkan.

Atas dukungan dan peran serta nyata dari orangtua dan masyarakat, sekolah dapat merawat gedung dan melengkapi sarana belajar dan membelajarkan termasuk mushola, melakukan berbagai kegiatan ekstrakurikuler untuk mengembangkan kemampuan dan bakat siswa di bidang seni tari, seni lukis, seni musik, olah raga dan kegiatan pramuka. Hasilnya terlihat dari banyaknya piala yang diraih kedua sekolah itu di berbagai lomba. Prestasi demi prestasi membuat sekolah itu semakin dikenal dan menimbulkan kebanggaan sendiri bagi siswa dan orangtuanya. Usaha guru, siswa dan partisipasi orangtua tidak percuma atau sia-sia.

Di samping berbagai kejuaraan yang diraih, kedua sekolah ini juga cukup unggul dalam prestasi akademik. Hal ini terlihat dari angka kelulusan yang setiap tahun rata-rata di atas 95\% dan 96\% dari antaranya diterima di SMP Negeri 216, tetangga sebelahnya.

Kedua sekolah ini juga peka terhadap kemajuan teknologi informasi yang berkembang cepat dan dimanfaatkan di dunia kerja. Penggunaan komputer di semua bidang pekerjaan bukan hal yang asing dan baru lagi. Bahkan juru parkir pun telah menggunakan komputer. Siswa tidak boleh terjebak dalam gagap teknologi dan perlu sejak dini diakrabkan dalam kehidupan mereka melalui sekolah. Demikianlah kirakira pemikiran kedua Kepala SD itu. Akan tetapi menunggu program pengadaan peralatan komputer dari Pemerintah memerlukan waktu lama dan mungkin sia-sia, apalagi kedua sekolah ini bukan termasuk sekolah percontohan, apalagi kategori sekolah koalisi yang berstandar ASEAN. Mereka termasuk kelompok sekolah biasa-biasa, atau istilah lainnya adalah sekolah regular yang tidak mendapat perhatian atau perlakuan istimewa.

Mengharapkan dana dari orangtua, masyarakat atau sponsor nampaknya tidak mudah karena dana yang diperlukan cukup besar. Kedua Kepala SD itupun memutar otak dan mencari terobosan mewujudkan cita-cita memiliki sejumlah perangkat komputer untuk siswa belajar dan berlatih. Muncullah gagasan penggalangan dana melalui tabungan siswa. Menabung adalah juga kegiatan pendidikan untuk membentuk watak hemat dan berpikir untuk masa depan. Gagasan itu mendapat sambutan baik dari orang tua dan komite sekolah. Siswa pun mulai dari kelas 1 sampai kelas 6 berlomba menabung dalam pengelolaan sekolah. Masing-masing menabung ke sekolah sesuai dengan kemampuannya dengan menghemat dari uang jajannya atau sengaja dititipkan oleh orangtuanya. Hasilnya cukup melegakan. Dalam waktu satu bulan terkumpul dana sekitar Rp. 15.000.000. dan dapat dipergunakan untuk pengadaan perangkat komputer. Sekolah benar-benar ingin memaksimalkan penggunaan dana itu. Oleh karena itu sekolah tidak membeli komputer yang built in, tetapi dengan bantuan orang lain membeli komponenkomponen komputer dan merakit sendiri. Secara bertahap SDN Kenari No 07 dapat memiliki 24 unit komputer dan mampu membayar honorarium seorang instruktur. Hal yang tidak jauh berbeda juga dilakukan oleh SDN kenari No 08.

Dengan menggunakan sebagian dari ruang 
perpustakaan, sekolah menyelenggarakan pengenalan dan praktek penggunaan komputer untuk siswa mulai dari kelas 1 sampai dengan kelas 6 . Oleh karena dana yang dipergunakan untuk pengadaan komputer dan honorarium instruktur berasal dari tabungan peserta didik dan ketika mereka lulus, tabungan itu harus diserahkan secara utuh, maka dalam menggunakan komputer itu, siswa dikenakan biaya. Untuk setiap bulan siswa dikenakan biaya sebesar Rp. 20.000 dengan pemakaian satu jam per hari. Dengan demikian biaya pemakaian per jam tidak sampai Rp. 1.000 dan jauh lebih murah dibandingkan dengan di tempat penyewaan komputer yang paling murah $\mathrm{Rp}$. 3. 000 untuk setiap jam pemakaian.

Minat siswa mengenal dan menggunakan komputer sangat tinggi. Ruang komputer selalu penuh setiap hari dan siswa rela antri dan menunggu lama sampai mendapat giliran. Waktu menunggu dipergunakan membaca buku perpustakaan yang letaknya bersebelahan dengan ruang komputer. Siswa semakin kerasan tinggal di sekolah dan orangtua merasa aman.

\section{BOS Datang, Prakarsa Terpasung}

Pada tahun 2004 terjadi perubahan kebijakan Pemerintah dalam sistem pembiayaan penyelenggaraan pendidikan di sekolah, khususnya sekolah negeri. Sejumlah sekolah memperoleh dana untuk pengadaan sarana pendidikan seperti buku pelajaran pokok/buku teks dalam bentuk block grant. Dana itu bersumber dari Pemerintah Pusat dan dialokasikan ke sekolah melalui Pemerintah Daerah. Sekolah yang mendapat dana itu diproritaskan untuk sekolah yang benar-benar kekurangan dana karena partisipasi orangtua dan masyarakat sulit diharapkan. Tahun berikutnya muncul pula penyaluran dana ke sekolah melalui program Bantuan Operasional Sekolah (BOS). Dana itu disalurkan khususnya ke sekolah negeri yang mengalami kesulitan dana untuk penyelenggaraan pembelajaran. Pada umumnya sasaran dana itu adalah sekolah yang termasuk kategori reguler.

Penyaluran dana langsung ke sekolah dimaksudkan untuk mengurangi beban orangtua dan masyarakat. Dana yang dibebankan kepada orangtua disebut sebagai sumbangan. Besarnya disesuaikan dengan kemampuan ekonomi masing-masing orang tua serta merupakan kesepakatan bersama guru, kepala sekolah dan komite sekolah. Akan tetapi dalam prakteknya, partisipasi orangtua dan masyarakat itu terkesan "dipaksakan" dan komite sekolah seakanakan tidak mewadahi semua aspirasi orangtua dan masyarakat. Bahkan terdapat dugaan bahwa di sekolah tertentu terjadi "kolusi" antara kepala sekolah dengan pengurus komite sekolah, sehingga keadaannya menjadi runyam.

Di lain pihak tuntutan kepada Pemerintah untuk menyelenggarakan pendidikan murah atau gratis semakin nyaring disuarakan. Oleh karena itu, peranan pendanaan melalui program BOS semakin penting dan mendapat perhatian besar. Dana yang berjumlah Rp. 69.500 untuk setiap siswa per bulan itu bersumber dari Pemda DKI sebesar Rp. 50.000 dan Pemerintah Pusat sebesar Rp. 19.500. Dana itu harus dipergunakan sekolah secara efektif dan efisien sesuai dengan peruntukkan yang ditetapkan Pemerintah. Dana BS itu dipergunakan untuk:

1. uang formulir pendaftaran;

2. buku pelajaran pokok dan buku penunjang untuk perpustakaan;

3. biaya peningkatan mutu guru;

4. ujian sekolah, ulangan umum bersama, dan ulangan umum harian;

5. membeli bahan habis pakai seperti buku tulis, kapur tulis, pensil, dan bahan praktek;

6. membayar biaya perawatan ringan;

7. membayar daya dan jasa;

8. membayar honorarium guru dan tenaga kependidikan honorer;

9. membayar kegiatan kesiswaan; dan

10. memberi bantuan siswa miskin untuk biaya transport.

Di samping ketentuan penggunaan dana melalui program BOS itu, terdapat ketentuan lain. Sekolah yang memperoleh dana BOS tidak diperbolehkan menggalang dana dari orang tua murid dan masyarakat, biar pun bertujuan meningkatkan pelayanan pendidikan dan mendapat persetujuan dari komite sekolah.

Dilihat dari jumlah, besarnya dana per siswa memang dana BOS lebih besar dari dana sumbangan penyelenggaraan pendidikan yang dibebankan kepada setiap siswa (rata-rata Rp. 40.000) sebelum kedatangan dana BOS. Akan tetapi di luar SPP itu sekolah masih dimungkinkan untuk menggalang dana untuk keperluan khusus seperti pengembangan kegiatan ekstrakurikuler, ulangan, perawatan gedung, dan karya wisata. Tetapi dengan adanya dana BOS itu prakarsa kepala sekolah, guru, serta komite sekolah seakan-akan terpasung dan tidak berkembang. Berbagai upaya sekolah meningkatkan pelayanan dan mutu pembelajaran menjadi tersendat dan tidak berkembang.

Dana BOS yang diterima SDN Kenari No 07 dan No 08 tidak cukup untuk mendukung berbagai 
kegiatan pendidikan yang telah dirintis dan dikembangkan sebelumnya. Kedua sekolah itu tidak mampu lagi membiayai honorarium beberapa guru untuk kegiatan ekstrakurikuler. Sekolah juga tidak mampu membayar honorarium instruktur dan biaya perawatan komputer. Berbagai kegiatan ekstrakurikuler terpaksa dikurangi atau dihentikan. Sekolah tidak diperbolehkan memungut biaya untuk program pengenalan dan praktek komputer. Semua perangkat komputer terpaksa dilelang untuk dapat mengembalikan tabungan siswa. Keceriaan dan kemeriahan wajah-wajah siswa belajar sambil bermain dengan komputer tinggal kenangan.

Nasib program komputer di SDN Kenari No 07 tidak jauh berbeda. Perangkat komputer itu belum dilelang tetapi juga menjadi onggokan yang mubazir karena tidak mampu membayar honor instruktur dan biaya perawatannya. Belum terlihat prakarsa sekolah atau Komite Sekolah mengatasi masalah tersebut. Kepala Sekolah takut dan trauma sehinga berpikir lebih baik menunggu saja daripada nanti dipersalahkan. Mereka mencoba memaksimalkan pelayanan pendidikan dengan keadaan yang minimalis.

Kondisi perpustakaan kedua SD itu pun ikut loyo. Ruang perpustakaan terkesan sebagai gudang yang tidak tertata rapi. Berbagai peralatan disimpan di situ. Keadaannya sama sekali tidak menggambarkan perpustakaan yang sesungguhnya, sangat sempit, miskin koleksi, tidak ada meja baca atau kursi tempat duduk. Sulit dapat diharapkan perpustakaan yang demikian dapat menumbuhkan dan menggairahkan minat baca. Sulit juga dapat dimengerti keadaan perpustakaan yang demikian berada di tengah-tengah ibu kota Republik Indonesia. Keadaan yang demikian mungkin juga terjadi karena mati surinya prakarsa Kepala Sekolah, guru, dan Komite Sekolah untuk menghidupkan perpustakaan itu.

Sementara ada sekolah lain, nun jauh di daerah sana, yang juga dilanda keterbatasan dana yang lebih dahsyat, dapat beimprovisasi dengan berbagai gaya belajar dan membelajarkan, penuh semangat, hidup dan bergairah. Berbagai tanya dapat muncul menggelitik, apalagi mendengar ungkapan "Pendidikan bermutu tidak harus mahal dan pendidikan mahal belum tentu bermutu". Jawaban singkat, mungkin prakarsa, prakarsa semua pihak yang terkait dan ikut bertanggung jawab.

Kedua Kepala dan guru di SD itu juga sependapat bahwa walaupun terpasang spanduk di pintu gerbang beberapa sekolah yang berbunyi "Sekolah Gratis", pada hakikatnya orangtua siswa tetap saja menanggung sejumlah biaya untuk dapat menyekolahkan anaknya. Dana BOS tidak mencukupi untuk dipakai untuk membayar biaya transportasi setiap siswa dari rumah ke sekolah dan sebaliknya apalagi untuk membeli pakaian seragam termasuk topi dan sepatu. Dengan perkataan lain, dana penyelenggaraan pendidikan yang disediakan Pemerintah dan Pemerintah DKI Jakarta belum memungkinkan siswa dapat bersekolah dengan baik tanpa mengeluarkan biaya sama sekali atau gratis.

\section{Pengawasan yang Kaku Menakutkan}

Penuturan kedua Kepala SD itu mencerminkan kehati-hatian Pemerintah dalam menggunakan dana yang pada hakikatnya bersumber dari rakyat banyak. Pemerintah menghendaki dana operasional sekolah benar-benar dipergunakan secara tepat guna tanpa adanya kebocoran. Untuk itu Pemerintah membuat rambu-rambu dan memantau serta mengawasi sejauh mana kepala sekolah konsisten mengikuti ramburambu itu. Pengawas dari Inspektorat, BPKP, bahkan tidak tertutup kemungkinan dari BPK secara terencana dan teratur melakukan pengawasan yang intensif. Selain itu anggota DPRD DKI Jakarta yang juga merasa ikut berkepentingan dan bertanggung jawab atas penggunaan dana BOS, sangat peka terhadap suarasuara sumbang masyarakat yang belum tentu kebenarannya. Pemerintah juga menugasi LSM tertentu memantau penggunaan dana itu dan melaporkannya kepada Pemerintah dan publik apabila terjadi penyimpangan. Belum lagi wartawan yang giat mencari berita dan rajin berkunjung ke sekolah apabila mendengar gosip-gosip yang tidak sedap didengar tetapi menarik untuk dijadikan berita.

Pengawasan dari berbagai pihak yang datang bertubi-tubi itu membuat kepala sekolah menjadi ekstra hati-hati menggunakan dana BOS dan berpikir berulang kali untuk melakukan prakarsa dan kreatif mendayagunakan dana yang ada. Kehati-hatian itu juga membuat waktu dan pikiran kepala sekolah banyak tersita untuk mengurusi administrasi penggunaan dan pertanggungjawaban dana itu. Banyak waktu dan pikiran tersita melayani pemantau dan pemeriksa yang kadang-kadang terkesan lebih bersifat investigasi daripada melakukan pembinaan. Konsekuensi lain upaya-upaya untuk meningkatkan mutu proses dan mutu pembelajaran pun kurang mendapat perhatian. Berpikir mengamankan dana lebih banyak daripada masalah-masalah edukatif yang sebenarnya menjadi tugas utama mereka. Konsep MBS yang pernah mereka peroleh dan diskusikan di berbagai penataran, menjadi kabur dalam penerapannya. Lain teori, lain praktek. 
Kedua Kepala Sekolah itu juga sepakat bahwa resiko atau sanksi yang ditimpakan kepada Kepala Sekolah apabila ditemukan penyimpangan penggunaan dan BOS sangat berat. Kepala Sekolah dapat saja dicopot dari jabatannya atau dimutasikan ke sekolah lain. Secara mental pun mereka merasa tertekan. Adalah merupakan aib besar yang sangat memalukan apabila ditemukan mereka sebagi pendidik dan pembelajar, melakukan penyimpangan penggunaan dana atau dengan perkataan lain melakukan korupsi. Karena tidak tahan menanggung kondisi yang demikian beberapa Kepala Sekolah mengajukan pensiun lebih awal, pada usia 57 tahun yang seharusnya masih dapat aktif sampai usia 60 tahun. Langkah yang demikian mungkin juga diikuti oleh kedua Kepala SD itu.

\section{Optimisme Tidak Pernah Sirna}

Gambaran yang diberikan kedua Kepala Sekolah itu menunjukkan suasana yang mencekam tetapi tidak kelihatan secara nyata. Siswa masih bersuka ria bermain di lapangan. Wajah-wajah mereka kelihatan polos dan bergairah belajar. Guruguru pun kelihatan tampil disertai senyum ramah dan bangga sebagai pahlawan tanpa tanda jasa. Ketika bercerita, kedua Kepala Sekolah itu pun penuh semangat dan diselingi dengan guyonan segar sehingga percakapan pun diwarnai dengan derai tawa.

Menurut mereka asumsi bahwa desentralisasi pengelolaan sekolah atau MBS meningkatkan prakarsa sekolah tidak cocok dengan keadaan sekolah mereka pada waktu ini. Berprakarsa sudah terlambat dan kesiangan. Dalam suasana sekarang ini, kalangan akademisi sering dikalahkan oleh politisi, legalisator, dan birokrat. Namun dalam kondisi yang demikian pun mereka harus optimis dan sebagai pendidik dan pembelajar, mereka nampaknya tidak putus asa tetapi juga tidak teralu idealis.

Pengamatan proses pembelajaran dengan berfokus pada interaksi antara guru dan siswa dengan menggunakan format Flanders yang dikembangkan, menunjukkan bahwa guru masih lebih banyak berperan pada awal sampai akhir pembelajaran. Guru masih banyak memberikan penjelasan dan mengajukan pertanyaan. Jarang terlihat siswa mengajukan pertanyaan atau memberikan pendapat atas penjelasan guru akan tetapi memberikan jawaban apabila guru bertanya. Interaksi antar siswa dalam diskusi di kelas juga tidak terlihat. Dengan demikian suasan pembelajaran yang aktif, kreatif, efektif, efisien dan menyenangkan tidak begitu kentara dalam proses pembelajaran, walaupun wajah-wajah siswa siswa terlihat ceria dan bersemangat belajar. Keadaan sedemikian terjadi mungkin karena pengamatan dilakukan ketika siswa sedang dipersiapkan untuk menghadapi ujian. Suasana proses pembelajaran mungkin berbeda pada waktu-waktu sebelumnya, seperti informasi yang diperoleh dari guru yang masih teteap optimis bahwa mereka masih mampu mencapai target yang ditetapkan dalam kurikulum dan mutu hasil belajar tidak akan menurun dari semester atau tahun sebelumnya.

Optimisme juga nampaknya yang membuat lingkungan sekolah itu tetap bersih sampai ke WC siswa. Cat tembok luar gedung itu memang kelihatan mulai pudar dan di beberapa tempat terlihat mulai terkelupas. Namun tidak terlihat coretan-coretan di tembok atau sampah bertebaran. Di kolam setiap pojok halaman berbagai jenis ikan masih menggeliat hidup di air yang terlihat bening. Kebersihan itu masih terjaga karena penjaga sekolah nampaknya berdedikasi tinggi dengan imbalan ijin yang diberikan Kepala Sekolah untuk mengelola kantin di sekolah itu. Upaya ini juga merupakan salah satu sisa prakarsa yang memberikan hasil nyata.

\section{Diskusi}

Hasil pengamatan ke kedua SDN itu menunjukkan bahwa kebijakan desentralisasi pengelolaan pendidikan melalui MBS nampaknya belum berjalan sepenuhnya dan perangkat peraturan dan ketentuan yang dibuat khususnya yang berkaitan dengan dana membuat Kepala Sekolah menjadi terlampau berhati-hati dalam melakukan prakarsa untuk meningkatkan mutu proses pembelajaran. Keterbatasan dana yang disediakan Pemerintah dan Pemerintah DKI Jakarta belum memungkinkan setiap siswa memperoleh pelayanan pendidikan yang sepenuhnya gratis. Sistem pendanaan pendidikan termasuk tata cara pengawasannya cenderung membuat Kepala Sekolah dan guru kurang leluasa berprakarsa untuk mengembangkan proses pembelajaran secara kreatif, efektif, efisien, dan menyenangkan. Keadaan yang demikian sulit dapat memberikan harapan untuk meningkatnya proses dan mutu hasil pembelajaran di kedua SDN itu.

Menurut Kamus Besar Bahasa Indonesia (1994), prakarsa berarti inisiatif yang datang dari diri seseorang untuk melakukan sesuatu. Berprakarsa berarti melakukan sesuatu atas inisiatif sendiri sesuai dengan kemampuan yang dimilikinya, tanpa dipengaruhi oleh atau tergantung pada orang lain. Dalam konteks pendidikan di sekolah, prakarsa itu 
dapat berasal dari Kepala Sekolah, guru, siswa, orang tua, Komite Sekolah, atau Pemerintah Daerah. Akan tetapi prakarsa sekolah dalam tulisan ini difokuskan pada prakarsa yang berasal dari kepala sekolah dan guru dalam meningkatkan mutu proses pembelajaran. Proses pembelajaran dianggap sebagai faktor kuat untuk menghasilkan hasil pembelajaran yang bermutu. Dengan meningkatnya mutu proses pembelajaran diharapkan pada gilirannya terjadi juga peningkatan mutu hasil pembelajaran.

Pentingnya prakarsa sekolah ini dapat dimengerti karena pada hakikatnya pelaksanaan operasional pembelajaran terjadi di sekolah, lebih khusus lagi di dalam kelas, dan peranan Kepala Sekolah dan guru ikut menentukan keberhasilannya. Berbagai upaya telah dilakukan oleh Pemerintah dan masyarakat untuk meningkatkan mutu pendidikan di semua jenis dan jenjang pendidikan. Akan tetapi penyediaan dana, sarana, serta tenaga kependidikan dan guru tidak akan dapat meningkatkan mutu pendidikan secara optimal apabila tidak dibarengi dengan tumbuh serta berkembangnya prakarsa pada akar rumput tempat berlangsungnya proses pendidikan itu sendiri yaitu sekolah.

Prakarsa sekolah mencakup inisiatif sekolah dalam mencari dan mendayagunakan secara optimal sumber-sumber daya pendidikan yang baru dan yang telah ada dalam bentuk sarana, prasarana, dana, dan tenaga kependidikan untuk meningkatkan kualitas proses dan hasil belajar-membelajarkan baik di lingkungan maupun di luar sekolah. Dengan demikian prakarsa sekolah itu ditunjukkan secara nyata oleh guru, tenaga kependidikan, serta Kepala Sekolah sebagai pemimpin dan manajer di tingkat sekolah. Prakarsa sekolah itu dapat juga mengikutsertakan atau mendapat dukungan dari Komite Sekolah, orang tua, dan masyarakat setempat.

Prakarsa sekolah ternyata dapat mengatasi berbagai masalah pendidikan seperti kekurangan dana yang disediakan Pemerintah atau Yayasan, keterbatasan sarana dan sumber belajar, kenakalan siswa, kekurangan pendidik dan tenaga kependidikan. Bahkan prakarsa sekolah dapat meningkatkan proses belajar-membelajarkan sehingga suasana belajar menjadi lebih hidup dan lebih menyenangkan dan peserta didik menjadi lebih tertarik serta lebih termotivasi belajar sehingga mutu hasil belajar lebih meningkat. Hal ini terlihat sekali di SLTP Terbuka Qaryah Thayyibah yang terletak di desa Kalibening, Kecamatan Tingkir, Salatiga, Jawa Tengah. Berkat kerja keras pimpinan sekolah, para guru, dan masyarakat setempat, sekolah dengan biaya murah itu dikenal sampai ke mancanegara (Buletin Pusat Perbukuan, 2005: 16-18).

Akan tetapi hasil kajian awal ini menunjukkan bahwa prakarsa dipahami dalam arti yang sangat terbatas pada upaya-upaya sekolah mengatasi masalah-masalah yang berkaitan dengan dana atau sarana dan prasarana pendidikan sehingga prakarsa yang dilakukan mengarah pada hal-hal yang berkaitan dengan menajemen sekolah. Masih sedikit terlihat usaha sekolah memfokuskannya pada penerapan dan pengembangan kurikulum seperti menerapakan teknik-teknik yang kreatif dalam belajar-membelajarkan, memanfaatkan sumbersumber belajar dan melaksanakan berbagai teknik evaluasi hasil belajar.

Kedua Kepala SD itu nampaknya khawatir prakarsa itu bertentangan dengan ketentuan dan peraturan yang berlaku sehingga dapat berdampak pada sanksi kepada mereka atau sekolah itu sendiri. Dengan demikian, kebijakan melakukan manajemen berbasis sekolah dengan memberikan kewenangan kepada sekolah untuk mengelola pendidikan sesuai dengan kebutuhan dan lingkungan setempat belum sepenuhnya menjamin menumbuhkan dan mengembangkan prakarsa sekolah.

Kebijakan desentralisasi pengelolaan pendidikan ke daerah bermaksud agar penyelenggaraan pendidikan itu lebih menyatu dengan masyarakat dan lingkungan setempat dalam arti tujuan dan isi pendidikan di sekolah memperhatikan kebutuhan, keadaan, dan peran serta masyarakat di sekitarnya di samping berorientasi pada tujuan pendidikan nasional. Pendidikan yang bermutu antara lain ditentukan bagaimana lembaga pendidikan itu, dalam hal ini sekolah, dapat memenuhi kebutuhan masyarakat dan lingkungannya (Sallis, 1994: 12). Akan tetapi apabila kewenangan yang diperoleh sekolah untuk mengelola proses pembelajaran tidak dapat mendorong prakarsa kepala sekolah dan guru karena berbagai kekhawatiran atas resiko peraturan dan ketentuan yang ada, maka pelimpahan wewenang ke sekolah dalam manajemen berbasis sekolah itu kurang dapat meningkatkan mutu proses dan hasil pembelajaran.

Pengalokasian dana langsung ke sekolah melalui Block Grant dan BOS disertai dengan ketentuan-ketentuan penggunaan dan pertanggungjawaban yang ketat dengan tujuan agar dana itu dipergunakan tepat sasaran dan efisien, malah membuat sekolah menjadi kaku dalam melaksanakan programnya dan tidak termotivasi melakukan prakarsa mengembangkan kegiatan pendidikan di 
sekolahnya. Kondisi seperti ini terlihat di sekolah tertentu yang mengurangi kegiatan pendidikannya karena dana BOS tidak dapat mendukung kegiatan yang sebelumnya didanai dengan sumber-sumber yang diprakarsai sekolah atas persetujuan komite sekolah. Sekolah yang mengalami keadaan yang demikian menunjukkan gejala kurangnya pemahaman kepala sekolah dan Pemerintah Daerah serta Dinas Pendidikan atas hakikat dan tujuan penyediaan dana melalui Block Grant dan BOS itu. Dilihat dari aspek sekolah berarti lingkup wewenang (discretion of power) yang diberikan kepadanya kurang dipahami. Dilihat dari Pemerintah Daerah atau Dinas Pendidikan, kebijakan desentralisasi pengambilan keputusan dalam pengelolaan keputusan kurang dimaknai sebagaimana cara untuk memberdayakan sekolah sesuai dengan keadaan dan permasalahan yang dihadapinya. Penyerahan wewenang ke organisasi tingkat pelaksana (sekolah), diharapkan pengambilan keputusan dapat dilakukan dengan cepat dan tepat sesuai dengan keadaan yang dihadapi tanpa mengabaikan tujuan organisasi secara menyeluruh (tujuan pendidikan nasional), sehingga penyelenggaraan organisasi (sekolah) dapat lebih efisien dan efektif. (Simon, 1997: 317-318)

Dibandingkan dengan sekolah swasta, mereka mungkin memiliki kebebasan yang lebih luas dan keberanian yang lebih besar dalam melakukan prakarsa dengan tujuan meningkatkan pelayanan dan mutu pendidikan untuk mempertahankan serta meningkatkan eksistensi dan popularitasnya. Kewenangan yang dimiliki swasta mengelola penyelenggaraan pendidikan di sekolahnya lebih luas dari sekolah negeri. Sekolah swasta lebih peka terhadap tuntutan masyarakat dan lingkungannya lincah melakukan perubahan untuk meningkatkan mutu pelayanan kepada pelanggannya. Bagi sekolah swasta tertentu bantuan dana yang diberikan Pemerintah mungkin juga ditanggapi sebagai pemicu untuk mengembangkan kegiatannya sehinga dapat memberikan pelayanan yang lebih baik serta meningkatkan mutu pendidikannya. Akan tetapi tidak tertutup juga kemungkinan terdapat sekolah swasta yang enggan menerima bantuan itu karena ketentuan-ketentuan dan sanksi yang menyertai dana bantuan itu dianggap merepotkan, padahal sekolah tersebut memiliki sumber dana yang memadai untuk melakukan berbagai prakarsa dalam meningkatkan mutu. Sekolah swasta cenderung lebih cekatan menerapkan prinsip-prinsip organisasi belajar (Marquardt, 1996: 2) dan menjaga keseimbangan (equilibrium) organisasi (sekolah) sehingga dapat bertahan, berkembang dan bersaing dengan tetap mengedepankan efisiensi (Simon, 1997:147)

Kedudukan dan peranan pengambil kebijakan di daerah nampaknya turut serta menentukan tumbuh dan berkembangnya prakarsa sekolah. Kepala daerah yang memberikan perhatian besar terhadap pendidikan dengan memberikan kemudahankemudahan dan dukungan kepada sekolah untuk kreatif mengembangkan dan mengoptimalkan sumber daya yang dimiliki sekolah, ternyata membuat sekolah lebih bebas dan leluasa secara kompetetif meningkatkan mutu proses dan hasil belajar di sekolah melalui berbagai prakarsa yang dilakukan oleh kepala sekolah dan guru. Sikap pimpinan daerah yang lebih bersifat membina daripada mengawasi itu ternyata juga dapat memberdayakan komite sekolah serta orang tua dan masyarakat sekitar memberikan dukungan atas kegiatan-kegiatan yang diprakarsai oleh sekolah untuk meningkatkan mutu pembelajaran. Sementara itu pimpinan daerah yang cenderung bersifat mengawasi dengan menggunakan ketentuanketentuan dan peraturan-peraturan secara kaku serta kurang memperdulikan kondisi dan masalah-masalah di sekolah, kelihatannya membendung kreativitas dan prakarsa sekolah untuk meningkatkan mutu pembelajaran. Bahkan beberapa sekolah mungkin tidak mampu menghabiskan dana bantuan operasional sekolah karena ketat dan kakunya aturan pemakaiannya.

Figur kepala sekolah sebagai pemimpin dan manajer di sekolah memberikan pengaruh yang besar dalam penyelenggaraan pendidikan di sekolah khususnya dalam proses belajar dan membelajarkan (Sallis, 1994:86-87). Kepala sekolah yang demokratis serta memberikan keleluasaan kepada dan/atau mendorong masing-masing pendidik untuk berimprovisasi dalam membelajarkan peserta didik dapat mengungkit kreativitas mereka. Bahkan di sekolah tertentu, kepala sekolah menyediakan forum khusus kepada pendidik untuk melakukan diskusi menemukan berbagai alternatif pemecahan masalah belajar-membelajarkan di dalam kelas sehingga peningkatan mutu proses dan hasilnya dapat dilakukan secara berkesinambungan. Berkembangnya prakarsa guru sebagai hasil dari pola kepemimpinan kepala sekolah lebih lanjut mendorong kepala sekolah untuk lebih kreatif membina dan meningkatkannya. Namun di sekolah yang kepala sekolah mengutamakan kepatuhan terhadap peraturan dan ketentuan yang mengalir melalui garis komando melahirkan pola kepemimpinan yang baku dan kaku sehingga kurang bahkan sering tidak 
memacu prakarsa guru dan kepala sekolah sendiri untuk mengatasi masalah-masalah belajarmembelajarkan di sekolah dan upaya peningkatan mutu dan hasil pembelajaran mengalami kemandegan.

Kegiatan belajar-membelajarkan secara nyata dapat dilihat di lingkungan sekolah, khususnya di ruang kelas melalui interaksi antara guru dan siswa dengan menggunakan berbagai sumber belajar. Hasil pengamatan di kedua SD itu memperlihatkan bahwa sungguhpun secara teoritis guru mengetahui berbagai pendekatan, metode, dan teknik belajar-membelajarkan secara umum, dalam pelaksanaan di kelas ternyata belum begtu terlihat prakarsa guru meningkatkan mutu pembelajaran yang sungguh-sungguh mengacu pada karakteristik peserta didik, kondisi ruang belajar/kelas, karakterisik bahan ajar, dan tujuan pembelajaran. Peranan guru ternyata masih menonjol, metode pembelajaran masih kurang bervariasi, pemanfaatan sumber-sumber belajar masih terbatas, pengelolaan kelas belum menciptakaan suasana dan pengalaman belajar yang dinamis dan menyenangkan, serta teknik evaluasi yang masih konvensional. Dalam keadaan yang demikian sulit dapat diharapkan terjadi peningkatan mutu pembelajaran.

Dilihat dari fungsinya sekolah dapat dikategorikan sebagai sekolah reguler, binaan proyek, koalisi, atau jenis lain seperti sekolah alternatif, sekolah unggulan, dan sekolah akseleratif. Kedua SD yang diamati termasuk sekolah reguler yang cenderung melakukan kegiatan belajar-membelajarkan secara rutinitas sehingga sulit dapat diharapkan mengalami peningkatan mutu yang cepat. Berbeda dengan sekolah yang dibina oleh proyek atau koalisi, yang melakukan berbagai improvisasi dalam meningkatkan mutu proses dan hasil belajarmembelajarkan karena guru dan Kepala Sekolah diberikan kewenangan dan kemudahan dalam melakukan dan mengembangkan prakarsa. Bahkan di daerah tertentu, Pemerintah Daerah memberikan kemudahan-kemudahan kepada sekolah binaan proyek itu agar dapat lebih berkembang dan bermutu sehingga dapat dijadikan sebagai model. Hal ini terlihat di sekolah-sekolah binaan Managing Basic Education (MBE) di Jakarta dan di beberapa daerah di Indonesia (Suara MBE, 2006).

Lokasi dan lingkungan sekolah ternyata tidak menentukan keberanekaragaman dan kualitas prakarsa yang dilakukan sekolah. Di sejumlah sekolah yang berlokasi di pedesaan dan masyarakatnya tidak begitu peduli dengan mutu pendidikan, terlihat menonjol prakarsa sekolah untuk meningkatkan mutu pembelajaran dan pengaruhnya kemudian tertular ke sekolah sekitarnya, bahkan merambat ke sekolah perkotaan. Tetapi di daerah pedesaan juga terdapat sekolah yang tidak menunjukkan prakarsa yang berarti. Sementara itu di sekolah perkotaan yang masyarakat sekitarnya cukup peduli terhadap pendidikan yang bermutu, tidak selalu terlihat prakarsa sekolah yang bertujuan meningkatkan mutu pembelajaran. Sedangkan di sekolah tertentu di daerah perkotaan juga terlihat semarak dengan berbagai prakarsa. Temuan penelitian ini tidak berbeda dengan yang terjadi di sekolah-sekolah binaan MBE di daerah Jawa Tengah dan Jawa Timur ( Suara MBE, 2006)

Informasi yang diperoleh dari kedua SDN itu antara lain menunjukkan, tumbuh dan berkembangnya prakarsa Kepala Sekolah dan guru dalam meningkatkan mutu proses pembelajaran banyak tergantung pada kepedulian dan komitmen pengambil keputusan terhadap pentingnya pendidikan bermutu untuk membangun masyarakat Indonesia yang beriman, berilmu dan bertanggung jawab. Kesan yang demikian adalah masuk di akal mengingat kultur masyarakat Indonesia yang pada umumnya masih berorientasi ke atas atau pimpinan. Berbagai prakarsa dapat saja bekembang dan berhasil apabila didukung oleh pimpinan dan unsur pengawas, dan sebaliknya juga tidak jarang terjadi.

Prakarsa sekolah sangat penting dalam mengatasi masalah-masalah pembelajaran serta meningkatkan mutu proses pembelajaran di sekolah. Akan tetapi, prakarsa tersebut belum tumbuh dan berkembang di kedua sekolah itu karena berbagai hambatan yang berkaitan dengan manajemen sekolah, tenaga kependidikan, dana, sarana dan prasarana, partisipasi masyarakat, pengawasan dan pembinaan. Oleh karena itu, apabila prakarsa sekolah ingin ditumbuhkembangkan maka perlu penyempurnaan pada unsur-unsur tersebut.

Berorentasi ke atas itu pulalah antara lain yang membuat Kepala Sekolah dan guru cenderung bersifat menunggu penjelasan dan petunjuk teknis dalam menjalankan suatu kebijakan. Sikap yang seperti ini dapat juga terjadi karena kekurangmampuan berprakarsa akibatnya pengetahuan dan pengalaman yang minim. Situasi yang demikian inilah mungkin mendorong perlunya peningkatan kualitas mutu guru, kepala sekolah, tenaga kependidikan lainnya, komite sekolah, aparatur Dinas Pendidikan dan Pemerintah Daerah yang terkait dengan pengelolaan pendidikan. Dengan memperhatikan pengalaman upaya-upaya peningkatan mutu sumber daya manusia itu tidak secara otomatis dapat mengubah keadaan atau memecahkan masalah di sekolah, maka 
perlu dikaji, dirancang dan dilaksanakan suatu sistem peningkatan mutu sumber daya pendidikan secara terpadu, terintegrasi, terkoordinasi dan komprehensif. Melakukan pekerjaan yang demikian merupakan tantangan berat, mengingat besarnya jumlah yang terlibat dan luas serta keberanekaragaman wilayah Indonesia.

Pengamatan yang dilakukan terbatas di dua SD Negeri yang berlokasi di DKI Jakarta dan hasil pengamatan tersebut tentu tidak dapat dijadikan bahan untuk keperluan generalisasi. Akan tetapi data dan informasi yang diperoleh mungkin dapat mengusik pikiran untuk melakukan penelitian yang sejenis di sekolah lain secara lebih luas. Karakteristik sekolah yang berbeda mungkin menghasilkan data, informasi, analisis, dan kesimpulan ang berbeda. Akan tetapi kalau keadaan di kedua SDN yang nota bene berada di tengah-tengah kota metropolitan dan sekaligus merupakan ibukota Negara Republik Indonesia, bagaimana dengan daerah lain? Mudah-mudahan menarik untuk diteliti lebih lanjut.

\section{DAFTAR PUSTAKA}

Cunningham, W.G. \& Cordeiro. P.A. (2003). Educational leadership: A problem-based approach. Boston: Pearson Education.

Gelsthorpe, T. \& West-Burnham, J. (Eds). (2003). Educational leadership and the community: Strategies for school improvement through community engagement. London: Pearson Education.
Himpunan peraturan perundang-undangan: Standar nasional pendidikan. (2005). Jakarta: Fokusmedia.

Kamus Besar Bahasa Indonesia. (1994). Jakarta: Balai Pustaka

Marquardt, M. J. (1996). Building the learning organization. New York: McGraw-Hill.

Miarso, Y. (2004). Menyemai benih teknologi pendidikan. Jakarta: Kencana bekerjasama dengan Pustekom Diknas.

Sallis, E. (1994). Total quality managemen in education. Philadelphia: Kogan Page.

Simon, H.A. (1997). Administrative behavior: A Study of a decision making processes in administraive educations. New York: The Free Press.

SLTP Terbuka Qaryah Thayyibah: Sekolah "Global" di kaki gunung Merbabu. (2005, Januari-Juni). Buletin Pusat Perbukuan. P. 16-18.

Suara MBE. (2006, April). Jakarta: RTI International

UUD 1945: Hasil amandemen \& proses amandemen UUD 1945 secara lengkap (pertama 1999 - Keempat 2002). (2002). Jakarta: Sinar Grafika.

\section{KETERANGAN PENULIS}

Dr. B. P. Sitepu, M.A. menjadi dosen tetap di Jurusan Teknologi Pendidikan, Fakultas Ilmu Pendidikan, UNJ sejak tahun 2002 setelah sebelumnya bertugas sebagai tenaga administratif di berbagai unit kerja di lingkungan Depdiknas. Di samping aktif menulis dalam berbagai jurnal ilmiah, juga menulis beberapa buku yang diterbitkan secara nasional. 